\title{
New Performance Measurement Trends: Evidence from Selected Multinational Corporations
}

\author{
Murtala Zakari \\ Post Graduate School of Accounting and Finance, Leeds Beckett University, Leeds, UK
}

Email address:

murhafs2010@gmail.com,murhab2015@gmail.com

To cite this article:

Murtala Zakari. New Performance Measurement Trends: Evidence from Selected Multinational Corporations. Journal of World Economic Research. Vol. 6, No. 4, 2017, pp. 54-58. doi: 10.11648/j.jwer.20170604.12

Received: May 28, 2017; Accepted: June 15, 2017; Published: July 20, 2017

\begin{abstract}
This study seeks to examine new trends in the performance measurement system over the traditional system, how corporate organizations respond to the emerging trends, how the changes impact their businesses performance in the challenging contemporary business environment, and identify the new approaches adopted to manage the changes. To achieve this, data were collected through the deployment of case studies and analyzed content of the case studies results. As a major contribution, this study enlightens readers with new insights on performance measurement. It also provides useful guidelines for effective measurement of performance. Findings from the analysis show that traditional performance appraisals were no longer working and the business corporations are now adopting new performance measurement such as individual check-ins, team touch points, and individual development plan (IDP). The study concludes that traditional performance measurement systems such as profitability, strict working capital, revenue, volume, cash flow, return on capital employed, etc were falling short of meeting the needs of managers in a much changed business environment. It has become increasingly important for organizations to develop systems of performance measurement which reflect the growing complexity of the business environment, monitor their strategic response to this complexity.
\end{abstract}

Keywords: Performance Measurement, Traditional System, Individual Check-ins, Team Touch Point, Individual Development Plan

\section{Introduction}

The recent trend in performance measurement is that companies are aligning human resources initiatives with the overall goals of the organization to improve business success. Aligning employee performance management with corporate performance management has significant benefits. $90 \%$ of surveyed companies perceived that improved management of their workforce was key to gaining competitive advantage [1]. Years of research has found that performance management practice is ineffective at boosting performance. [10], a world leader in driving corporate performance recently conducted a global survey on performance management system and found that; $59 \%$ of employees feel performance reviews are not worth the time invested, $95 \%$ of managers are dissatisfied with their performance reviews/management systems, two-thirds of performance management systems misidentify high performers, regardless of force rankings, and $56 \%$ said they do not receive feedback on what to improve. This development has made world-class organizations rethink their performance management approach, such as Lafargeholcim Group, Cargill, Accenture, General Electric, Adobe, Deloitte, Eli Lilly, Google, etc.

Performance measurement has been well researched in the literature with conceptual framework and models, particularly the balance scorecard. However, what has not been examined in recent times, is how to ensure that performance measurement evolve in tandem with the contemporary business environments [19]. In the same vein, [4] argued that contemporary methods do not adequately address the challenges associated with managing performance in an increasingly contemporary business environment. Therefore, there is a gap in understanding how organizations manage change in their performance measurement in practice [7].

To this end, this study aims to examine new trends in the performance measurement system over the traditional system, how corporate organizations respond to the emerging 
trends, how the changes impact their businesses performance in the challenging contemporary business environment, and to identify the new approaches adopted to manage the changes. This study enlightens readers with new insights on performance measurement. It also provides useful guidelines for effective measurement of performance.

\section{Literature Review}

[22] opined that traditional performance measurement systems such as profitability, cash flow and return on capital employed were falling short of meeting the needs of managers in a much changed business environment. [6] maintains that organizations have extensive performance measurement systems based on cost and financial accounting practices. However, because these techniques are based on old fashion such as overhead absorption methods, they fail to support the current business objectives and do not enable continuous improvement. [6] opined that even the recent innovations such as Activity Based Costing (ABC) improves allocation methods but does not promote continuous improvement and strategic orientation. Similar empirical evidence that conform to Bititci's position was the work of Kaplan (1990 and 1993) and Johnson and Kaplan (1987) cited in [6] in which case they also recognized these weaknesses. Neely (1993) cited in [6] pointed short comings of the current accounting practices with respect to performance measurement in manufacturing enterprises. Neely (1993) opined that financial measures that are currently in place in the manufacturing enterprises such as financial ratios, return on equity, etc. are not supporting the change process, there is a case for new styles of measurement systems that are appropriate to the needs of the modern manufacturing industry devoid of manipulation.

In the light of the above, it could be argued that the limitation of traditional performance measurement is the emphasis on measurable KPIs without recourse to employees expected behaviours, and development, these performance measurements are profitability, cash flow, return on capital employed, strict working capital (SWC), earnings before interest, tax, depreciation, and amortization (EBITDA), costs savings, etc. without paying attention to non-financial measures like individual check-ins conversation between an employee and his/her manager, and team touch points between team and their manager to check for alignment, see how the team is doing in adding value to the business and what is required to do so, provide opportunity for feedback from peers and managers, both positive and constructive which brings greater improvement of team effectiveness and team ownership.

Performance measurement evolves and changes, and impacts corporate environment, this calls for strategies to manage the impact. These strategies and business environments are dynamic in nature, business organizations need to ensure that they are capable of managing change in their performance measurement $[6,18]$. Sticking to a performance measurement for too long has been described by [21] as one of the five traps of performance measurement.
Performance measurement as cited in [24] is used in organizations for a wide array of reasons; to gauge performance (Slack et al., 2004), direct behaviour and improve motivation (Spitzer, 2007), continuously improve processes (Cross and Lynch, 1992), enhance productivity (Bernolak, 1997), identify areas of attention, improve communication, increase accountability (Waggoner et al., 1999), implement strategy (Kaplan and Norton, 2001), support goal achievement (Tapinos et al., 2005) and provide information on strategy implementation (Neely, 1999). Regardless of the reason to why Performance measurement are deployed, it is widely recognized in the literature that Performance measurement need to be aligned with the strategic priorities, as well as the internal and external environments of the organization (Neely et al., 1996; Bourne et al., 2000; Bititci et al., 2001 cited in [24]). The performance measurement changes can be perceived from two perspectives, structural and behavioural. The structural perspective stresses the need for processes, mechanisms and procedures for managing performance measurement change. However, within the structural perspective, emphasis is put on the capabilities and flexibility of the IT-systems. The need to have a process, mechanism, procedure in place for continuously reviewing and changing performance measurement is a feature that the researchers in general highlight as important [24]. However, how the process, mechanism, and procedures ought to be designed and function is not agreed upon. Some frameworks (Neely et al., 2002a; Bourne et al., 2000) as cited in [24], elaborate on the responsibilities of such a process but provide little direction on how it might take shape in practice. However, from a behavioural perspective, the role of senior management, culture and employees involvement or empowerment are all underlined as important factors (Waggoner et al., 1999; Kennerley and Neely, 2002; Kennerley and Neely, 2003; Salloum and Wiktorsson, 2011 cited in [24]).

One of the most popular changes in the performance measurement is the development of balanced scorecard. Originally developed as a performance measurement tool, the scorecard is now associated increasingly with strategy implementation. It acts as a management framework with the potential to identify and exploit organizations' key value drivers to their best strategic advantage [11]. [22] opined it is essential that the performance measurement systems adopted by an organization should fulfill the following functions:

(a) The measures chosen should link operations to strategic goals. It is vital that departments are aware of the extent to which they are contributing - separately and together - in achieving strategic aims.

(b) The measures chosen must make use of both financial and non-financial information in such a manner that is of value to departmental managers. In addition, the availability of the correct information as and when required is necessary to support decision-making at all levels within an organization.

(c) The real value of the system lies in its ability to focus all business activities on the requirements of its customers. 
Berry, Broadbent and Otley (1995) cited in [17] suggested that the following benefits can be derived from the use of performance measures: Clarification of the objectives of the organization; development of agreed measures of activity; a greater understanding of the processes within the organization; facilitation of comparisons of performance between different organizations; facilitation of the setting of targets for the organization and its managers, and promotion of the accountability of the organization to its stakeholders.

\section{Research Methodology}

In order to fulfill the purpose of this study, the data presented has been collected through the deployment of case studies. Data were also collected from related literature, academic articles, and internet sources. The data collected were reviewed critically to arrival at the theoretical findings of this study. The choice of case study as means for data collection stems from the possibility of an in-depth and holistic examination of the formulated phenomenon [23, 5]. The unit of analysis [25] in all six cases has been the way of working for managing change in performance measurement. The case study companies are; Lafargeholcim, Cargill, Accenture, General Electric, Adobe, Deloitte, and Google. Three factors have guided the selection of case companies; firstly, they are the big multinational companies that first responded to the performance measurement changes, secondly, the knowledge about the company practices that the researcher could obtain, thirdly, the possibility to get unrestricted access to the companies, performance management system either through their official websites, HR consultants, or their human resources representatives. Practical implications were analyzed with the help of previous surveys by Insala HR consulting, Clear review consulting and Fast Company consulting. The researcher has knowledge of some of the case companies with unrestricted access to the information on their performance measurement changes and their response to the changes. This research method is consistent with the one adopted by [24].

\section{Findings}

The following are the practical implications of performance measurement changes and the approaches the big companies are adopting to manage the trends;

\subsection{Lafargeholcim Group}

LafargeHolcim is a manufacturer of building materials which claims to be the largest in the world, with a presence in 90 countries and 115,000 employees. They are into manufacturing and selling of cement, aggregate and concrete head quarter in Zurich, Switzerland. They have joined the world-class organizations in rethinking their performance measurement approach because years of research have found that performance management practice is ineffective at boosting performance. However, the focus areas now are; identifying what to do and how to do it, the how is linked to employees behavior expected to exhibit in achieving the what to do. The new thing is the introduction of how to do it. This is yielding a positive result on performance. The second changes is the introduction of regular informal conversations (Individual Check-ins and Team Touch Point) between an employee and his/her line manager (Individual Check-ins), and between team and their line manager (Team Touch Point), this development is impacting positively on the business as employees know where they stand and can adjust.

\subsection{Cargill}

Cargill, Inc. is an American privately held global corporation based in Minnetonka, Minnesota, a Minneapolis suburb. Founded in 1865, it is now the largest privately held corporation in the United States in terms of revenue. Like Adobe, Cargill, the US food producer and distributer, started to transform its traditional performance management processes back in 2012 when it introduced what it called 'Everyday Performance Management'. It removed performance ratings and annual review forms and instead focused on managers having frequent, on-the-job conversations and giving regular, constructive feedback.

\subsection{Adobe Group}

Adobe Systems is an American multinational computer software company. The company is headquartered in San Jose, California, United States. Adobe is producing, marketing, and selling computer softwares. Adobe was the forerunners of change when they abandoned annual performance appraisals back in 2012. They replaced them with regular 'check-ins', i.e. informal discussion between an employee and his/her line manager supported by frequent feedback both positive and constructive. There are no ratings or rankings and they allow different parts of the organization to determine how frequently they should hold check-in conversations according to their work cycles. The result has been a marked increase in employee engagement, with voluntary turnover decreasing by $30 \%$ since check-ins were introduced.

\subsection{Accenture Group}

Accenture is a global professional services company and provides strategy, consulting, digital, technology and operations services. It has been incorporated in Dublin, Ireland, since 1st September, 2009. It is a Fortune Global 500 company. As of September 2015, Accenture, one of the largest companies in the world, disbanded their former ranking and once-a-year evaluation process. Like GE, Accenture have decided to put frequent feedback and conversations at the heart of their new process, and focus on performance development, rather than performance rating. As Ellyn Shook, Chief HR Officer at Accenture put it, "Rather than taking a retrospective view, people will engage in future-focused conversations about their aspirations, leading to actions to help them grow and progress their careers." 


\subsection{Deloitte}

Deloitte is the brand under which tens of thousands of dedicated professionals in independent firms throughout the world collaborate to provide audit, consulting, financial advisory, risk management, tax, and related services to select clients. These firms are members of Deloitte Touche Tohmatsu Limited, a UK private company limited by guarantee ("DTTL"). Deloitte were the first big name to announce in 2015 that they were scrapping once-a-year performance reviews, 360 degree feedback and objective cascading. This was after they calculated that these processes were consuming 2 million hours a year across their organization.

Deloitte's new process requires every team leader to check-in with each team member once a week to discuss near-term work and priorities, comment on recent work and provide coaching. To ensure this check-ins take place frequently, the check-ins is initiated by the team members rather than the team leaders

\subsection{General Electric Group}

General Electric, often abbreviated as GE, is an American multinational conglomerate corporation incorporated in New York, and headquartered in Boston, Massachusetts. They are into business of power, renewable energy, oil and gas, aviation, healthcare, etc. Under the reign of its former CEO, Jack Welsh, General Electric was the most well-known proponent of annual performance ratings and forced distribution curves. For decades, GE operated a 'rank and yank' system whereby employees were appraised and rated once a year, following which the bottom $10 \%$ were fired. Not exactly a recipe for employee engagement. In 2015 GE announced that it was replacing this approach with frequent feedback and regular conversations called 'touch points' to review progress against agreed goals.

\section{Conclusion}

Traditional performance measurement systems such as profitability, cash flow and return on capital employed were falling short of meeting the needs of managers in a much changed business environment. It has become increasingly important for organizations to develop systems of performance measurement which reflect the growing complexity of the business environment, monitor their strategic response to this complexity. The need for good performance management is an ongoing issue which would be embraced by the management of all organizations in the near future in view of its tremendous benefits. Poor performance or conduct needs to be addressed; not dealing with the situation is not a solution. Providing honest and timely feedback to trigger behavioural change is key. Corporate organizations are realizing progressively that much of their strategic value lies in their people, systems, processes and ability to innovate. The emphasis now on performance measurement is individual check-ins, team touch points, and individual development plan (IDP). Individual check-ins is a regular discussion on performance between the manager and the direct reports. Team touch points are team discussions to check for alignment, see how the team is doing in adding value to the business and what is required to do so. IDP entails development of competencies, behaviors, and knowledge to close performance gaps, skills gaps, role mismatch, and competency issues. A performance management system that focuses on behaviour, in addition to results becomes a business-risk management tool or a business-risk mitigation tool. The issue that usually arises is how an organization measures behaviour? Other behavioral issues include communication skills, leadership traits, codes of ethics/professional conduct, conflict management, etc. Incorporating the appraisal of behaviour in performance management system becomes a tool for building and sustaining a culture valued by consumers, potential investors, shareholders, regulators and other external interest groups. Negative behaviour that may affect performance measures includes being insubordination; rough relationship, individualistic, working in silo, passing the buck, nonchalant attitude, etc while positive behaviour includes hard working, teamwork, strong reputation for being collaborative, emotionally intelligent, etc. It could be argued that performance is a consequence of behaviour. It is important to measure the behaviours which result in a performance because it may have good or bad implications for the business. Results measure past performance while behaviour points to future performance. Clearly, measuring both employee and organizational behaviour is of strategic importance. Those who are against the formal evaluation of behaviour always advance the argument that measuring employee behaviour is difficult and highly subjective.

\section{References}

[1] Aberdeen Group (2005) 'Aligning Employee Performance Management (EPM) with Corporate Performance Management (CPM)', available from www.abergeengroup.com.

[2] Accenture Corporate Site, viewed 25th December 2016, from www.accenture.com.

[3] Adobe Corporate Site, viewed 1st January 2016, from www.adobe.com.

[4] Barrows, E. and Neely, A. (2012) "Managing Performance in Turbulent Times - Analytics and Insights". New Jersey, USA: John Wiley and Sons Inc.

[5] Bell, J. (1999) "Introduction till forskningsmetodik". Lund, Sweden: Student literature.

[6] Bititci, U. S., Carrie, A. S., McDevitt, L. (1997) "Integrated Performance Measurement Systems: A Development Guide". International Journal of Operations \& Production Management, 17 (6).

[7] Bourne, M., et al. (2000) "Designing, implementing and updating performance measurement systems". International Journal of Operations \& Production Management, 20 (7), pp. 754-771. 
[8] Bourne, M. (2008) "Performance measurement: learning from the past and projecting the future". Measuring Business Excellence, 12 (4), pp. 67-72.

[9] Cargil Corporate Site, viewed 25th December 2016, from www.cargill.co.uk.

[10] CEB Global (2015) "World-class organizations are rethinking their performance management approach", available from: www.cebglobal.com.

[11] CIMA (2005) "Effective Performance Management with the Balanced Scorecard Technical Report", London SW1P 4NP Printed in Great Britain.

[12] Clear Review (2016) 'What does performance management look like in 2016?' available from https://clearreview.com.

[13] Deloitte Corporate Site, viewed 25th December 2016, from www2.deloitte.com.

[14] Fast Company (2016) "Six companies that are redefining their performance management", available from www.fastcompany.com.

[15] General Electric Corporate Site, viewed 25th December 2016, from www.ge.com.

[16] Insala (2016) "Performance Management: Current Trends", available from: http://www.insala.com.

[17] Johnson, S. (2005) "The Pyramids and Pitfalls of Performance Measurement" available from http://www.accaglobal.com.
[18] Kennerley, M. and Neely, A. (2002) "A framework of the factors affecting the evolution of performance measurement systems". International Journal of Operations \& Production Management, 22 (11), pp. 1222-1245.

[19] Kennerley, M. and Neely, A. (2003) "Measuring performance in a changing business environment". International Journal of Operations \& Production Management, 23 (2), pp. 213-229.

[20] Lafarge Corporate Site, viewed $25^{\text {th }}$ December 2016, from www.lafargeholcim.com.

[21] Likierman, A. (2009) "The five traps of performance measurement'. Harvard Business Review, October, pp. 96101.

[22] Lynch, R. L, and Cross, K. F. (1991) "Measure up, Yardsticks for Continuous Improvement": USA, Blackwell, 1st edition.

[23] Merriam, S. B. (1994). Fallstudien som forskningsmetod. Lund, Sweden: Student literature.

[24] Salloum, M. and Cedergren, S. (2012) "Managing change in performance measures - An inter-company case study approach" Int. Journal of Business Science and Applied Management, Vol. 7, no. 2, pp. 53-66.

[25] Yin, R. K. (1994). "Case study research: Design and methods', California, USA: Sage Publications, 2nd edition. 